\title{
PHYSICOCHEMICAL AND MICROBIAL ANALYSIS OF FECES FROM HORSES FED DIETS CONTAINING CITRUS PULP
}

\section{ANÁLISES FISICOQUÍMICAS E MICROBIOLÓGICAS DE FEZES DE EQUINOS ALIMENTADOS COM DIETAS QUE CONTÉM POLPA CÍTRICA}

\author{
Roberta Ariboni Brandi ${ }^{*}$ \\ Adriana Moraes de Oliveira Tribucci ${ }^{2}$ \\ Júlio César de Carvalho Balieiro ${ }^{3}$ \\ Ricardo Luiz Moro de Souza ${ }^{2}$ \\ Alfredo Manuel Franco Pereira ${ }^{4}$ \\ Rhonda M. Hoffman ${ }^{5}$

\begin{abstract}
${ }^{1}$ Universidade Estadual Paulista, Faculdade de Ciências Agrárias e Tecnológicas de Dracena, Dracena, SP, Brasil.

2Universidade de São Paulo, Faculdade de Zootecnia e Engenharia de Alimentos, Pirassununga, SP, Brasil ${ }^{3}$ Universidade de São Paulo, Faculdade de Medicina Veterinária e Zootecnia, Pirassununga, SP, Brasil ¿Universidade de Évora, Évora, Portugal.

${ }^{5}$ School of Agribusiness and Agriscience at Middle Tennessee State University in Murfreesboro, Estados Unidos

*Correspondig author - robertabrandi@usp.br
\end{abstract}

\begin{abstract}
This study aimed to evaluate the effect of diets containing increasing levels of citrus pulp on the physicochemical and microbiological characteristics of horses feces. Five mares, at an average age of 3.5 years old and body weight of $492 \pm 44.5 \mathrm{~kg}$ were arranged in a 5 x 5 Latin Square. The experimental diet consisted of $60 \%$ coast-cross hay and $40 \%$ of concentrate with increasing levels of citrus pulp $(0,7,14,21$, and $28 \%)$. To determine the fecal $\mathrm{pH}$, samples were collected directly from the floor, immediately after defecation, in the first feces of the day at 07:00 a.m., and color and fecal consistency were evaluated. For microbiological analysis, an aliquot was reserved in plastic bags, frozen, and sent to the microbiological laboratory for further analysis. Lactic acid bacteria were counted for Lactobacillus spp. and Streptococcus spp. from fecal samples under anaerobic conditions. The diet produced differences $(P<0.05)$ in feces consistency: $98 \%$ of the animals had normal and firm stools, while $2 \%$ were loose ruminant-type feces. We observed no difference $(P<0.05)$ for color, verifying $100 \%$ of the animals of greenish feces, normal for equines. There was no effect $(P>0.05)$ on $\mathrm{pH}$ and on the number of Lactobacillus spp. and Streptococcus spp. The inclusion of up to $28 \%$ citrus pulp concentrates for horses did not promote change in the physicochemical characteristics and on the population of lactic acid-producing bacteria in feces.
\end{abstract}

Keywords: byproducts; lactobacillus; nutrition; $\mathrm{pH}$.

\section{Resumo}

O presente estudo teve como objetivo avaliar o efeito de dietas com níveis crescentes de polpa cítrica nas análises físico-químicas e microbiológicas nas fezes de cavalos. Cinco éguas, com idade média de 3,5 anos e peso corporal de $492 \pm 44.5 \mathrm{~kg}$ foram dispostas em um quadrado latino $5 \times 5$. As dietas experimentais consistiram de $60 \%$ de feno coast-cross e $40 \%$ de concentrado com níveis crescentes de polpa cítrica $(0,7,14,21,28 \%)$. Para determinar o $\mathrm{pH}$ fecal foram colhidas amostras (diretamente do reto) das primeiras fezes do dia às 07:00 min e foram avaliados as características de cor e consistência 
fecal. Para as análises microbiológicas, um alíquota foi reservada em plásticos, congeladas e enviadas para o laboratório para posterior análise. As bactérias láticas foram enumeradas por Lactobacillus spp. e Streptococcus spp. a partir das amostras fecais, em condições anaeróbicas. Não houve efeito $(\mathrm{P}<0,05)$ para a consistência fecal, $98 \%$ dos animais apresentaram fezes normais e firmes, enquanto $2 \%$ apresentaram fezes do tipo soltas. Não houve diferença $(\mathrm{P}<0,05)$ para a cor sendo que $100 \%$ dos animais apresentaram fezes verdes e normais. Não houve efeito $(\mathrm{P}>0,05)$ no $\mathrm{pH}$ e no número de Lactobacillus spp. e Streptococcus spp. A inclusão de até $28 \%$ de polpa cítrica no concentrado para equinos não promove mudanças nas características físico-químicas e na população de bactérias produtoras de ácido lático nas fezes.

Palavras-chave: lactobacillus; nutrição; $\mathrm{pH}$; subprodutos.

Enviado em: 16 outubro 2014

Aceito em 27 junho 2016

\section{Introduction}

An understanding of the physicochemical characteristics of feces can facilitate the diagnosis of intestinal acidosis and reduce risk of colic, endotoxemia, and laminitis ${ }^{(1)}$. The measurement of $\mathrm{pH}$, microbiota concentration, and short chain fatty acids (SCFA) has been previously used to determine the health of the digestive $\operatorname{tract}^{(2)}$. Regular defecation, consistency, shape, and smell of feces are important for the evaluation of equine digestive tract health, and this cannot be ignored in assessing the well-being and the dietary changes ${ }^{(2)}$.

Diet directly affects fecal $\mathrm{pH}$ and may cause gastrointestinal disturbances, especially when provided carelessly. Horses fed diets with higher intake of hydrolysable carbohydrates present a reduction in fecal $\mathrm{pH}^{(3)}$. The excessive consumption of hydrolysable carbohydrates overloads the capacity of the small intestine and results in rapid fermentation in the large intestine, leading to increased production of short chain fatty acids (SCFAs) and lactic acid. The supply of hay twice a day and the increase in the amount of dietary fiber are associated with increased fecal $\mathrm{pH}^{(4)}$. Hay and fodders rich in fibers can potentially slow fermentation in the large intestine and, due to its dry matter content, may soak up excess SCFA produced by fermentation ${ }^{(5)}$.

Currently, it is suggested that the maximum contribution of starch is $1 \mathrm{~g} / \mathrm{kg}$ body weight (BW) per meal $^{(6)}$. In view of reducing the overload of starch in the diets of horses, new ingredients have been tested, among them byproducts such as citrus pulp and soybean hulls ${ }^{(7)}$, which have similar energy amount to grains ${ }^{(8)}$. Citrus pulp presents good alternative energy and high proportion of neutral detergent fiber (NDF) and acid detergent fiber (ADF) ${ }^{(5)}$.

However, changes in the diet composition may lead to changes in the gastrointestinal microbial ecology, creating favorable conditions for the gastrointestinal imbalance with the proliferation of lactic acid-producing bacteria (LAB), thus sparking acidosis and equine laminitis ${ }^{(9)}$. Therefore, monitoring populations of $\mathrm{LAB}$ as a reflection of a potentially imbalanced microflora are essential when considering dietary ingredients. The aim of this study was to evaluate the effect of diets with increasing levels of citrus pulp on the physiochemical and microbial content of feces.

\section{Materials and Methods}

The experiment was conducted at the Department of Equines of the City Hall of Pirassununga Campus, São Paulo, Brazil, in 2011. We used five crossbred horses, aged approximately 3.5 years, with body weight of $492.5 \pm 44.5 \mathrm{~kg}$, housed in individual box stalls. The animals adjusted to the diet for seven days, followed by three days of total collection of feces, and four days of rest. No significant body weight changes were observed during the experiment. 
The animals were arranged in 5 x 5 Latin square (five horses and five diets). The experimental diets were formulated attending the requirement of maintaining animals as described by National Research Council $^{(5)}$. The proportion of forage:concentrate was 60:40, and the roughage used was coast-cross hay. The experimental concentrates were formulated with increasing levels of citrus pulp (Tables 1 and 2). The citrus pulp was obtained by processing oranges using the pressing technique with subsequent drying. In order to facilitate drying of the citrus pulp feed product, calcium oxide was added to release the bound juices and reduce the stickiness of the pulp, which otherwise can result in charring. The chemical composition of the citrus pulp used was as follows: $90.26 \%$ dry matter, 7.26 $\%$ ash, $7.32 \%$ crude protein, $12.31 \%$ crude fiber, $1.65 \%$ ether extract, $14.72 \% \mathrm{ADF}$, and $20.17 \%$ NDF.

Table 1. Percentage composition of the experimental concentrates

\begin{tabular}{lccccc}
\hline \multicolumn{1}{c}{ Ingredient } & \multicolumn{5}{c}{ Levels of citrus pulp (\%) } \\
\hline & $\mathbf{0}$ & 7 & $\mathbf{1 4}$ & $\mathbf{2 1}$ & $\mathbf{2 8}$ \\
\hline Ground corn & 78.6 & 73.0 & 67.4 & 61.1 & 54.9 \\
Soybean meal & 10 & 10 & 10.2 & 10.9 & 11.6 \\
Wheat bran & 7.4 & 5.8 & 4.3 & 2.8 & 1.3 \\
Citrus pulp & 0 & 7 & 14 & 21 & 28 \\
Premix* & 2 & 2 & 2 & 2 & 2 \\
Salt & 1 & 1 & 1 & 1 & 1 \\
Limestone & 0.95 & 0.95 & 0.95 & 0.95 & 0.95 \\
Dicalcium & 0.2 & 0.2 & 0.2 & 0.2 & 0.2 \\
\hline
\end{tabular}

* Higher Guarantee: manganese monoxide $(11,400.00 \mathrm{mg})$; additive antioxidant (25.00 mg), calcium iodate $(26.00 \mathrm{mg})$, sodium Selenite $(48.00 \mathrm{mg})$, vitamin B12 $(2,500.00 \mathrm{mcg})$, calcium pantothenate $(1500.00 \mathrm{mg})$, biotin $(20.00 \mathrm{mg})$, vitamin B6 (764.00 mg), choline chloride $(12858.00 \mathrm{mg})$, vitamin $\mathrm{E}$ $(10000.00 \mathrm{IU} / \mathrm{kg})$, vitamin A (IU $1500.000,00 / \mathrm{kg})$; vitamin K3 (240.00 mg), vitamin D3 $(150,000.00$ $\mathrm{IU} / \mathrm{kg}$ ), iron $(21780.00 \mathrm{mg})$, zinc oxide $(25000.00 \mathrm{mg})$, copper sulfate $(6250.00 \mathrm{mg})$, cobalt sulfate $(25.00 \mathrm{mg})$, folic acid $(505.00 \mathrm{mg})$, niacin $(2512.00 \mathrm{mg})$, vitamin B2 $(1250.00 \mathrm{mg})$.

The chemical analysis of the diets was completed at the Food Science Laboratory of ZAZ, and microbiological analysis was completed in the Zootechnical ZMV Hygiene Laboratory ZMV-FZEAUSP. For determination of $\mathrm{pH}$, stool samples were collected in plastic bags, directly from the floor at 07:00 h, during three consecutive days and sent immediately to the laboratory, where the $\mathrm{pH}$ was measured introducing the fresh feces to $\mathrm{pH}$ meter directly. For microbiological analysis an aliquot was reserved in the plastic bags, frozen and sent to the microbiological laboratory for further analysis.

The classification of the characteristics regarding consistency and color of feces was performed with the aid of a score sheet ${ }^{(10)}$. At the same time, fecal $\mathrm{pH}$ was evaluated, using the method of Berg et al. (2). For microbiological analysis, $10 \mathrm{~g}$ of each fecal sample was homogenized with $100 \mathrm{~mL}$ of sterile peptone water $0.1 \%(\mathrm{w} / \mathrm{v})$, making it a starting dilution of $10^{-1}$. The $10^{-1}$ starting dilution was further diluted to $10^{-8}$, and fecal samples were plated $(100 \mathrm{~mL})$ on Columbia Agar supplemented with either 5\% defibrinated sheep blood (New Prov Ltda., Brazil), or Agar Man, Rogosa, Sharpe modified (LAMVAB) ${ }^{(11)}$, respectively, for growth of Streptococcus spp. and Lactobacillus spp. under anaerobic conditions for 24 to 48 hours at $37^{\circ} \mathrm{C}$. The bacterial counts were recorded as colony forming units (CFU) per gram of feces and expressed as $\log \mathrm{CFU} \mathrm{g} \mathrm{g}^{-1}$ of feces.

Quantitative parameters were analyzed according to the statistical model $\mathbf{y i j k}=\boldsymbol{\mu}+\mathbf{A} \mathbf{i}+\mathbf{T} \mathbf{j}+\mathbf{P k}+$ عijk, where yijk represents the dependent variable; $\mu$ the overall mean; Ai, the effect of the animal ( $i=$ 1 to 5); $\mathrm{Tj}$, the treatment effect ( $\mathrm{j}=1$ to 5); $\mathrm{Pk}$, the effect of the period $(\mathrm{k}=1$ to 5); and cijk the residual error. For statistical analysis, the PROC GLM of SAS statistical package for Windows ${ }^{(12)}$ was used, and means were compared by Tukey test with a probability level of 5\%. A chi-square test was used for the evaluation of the frequency parameters of fecal consistency and color. Comparisons between 
the results obtained for the bacterial counts from different samples, considering the different diets and the control group were performed using simple analysis of variance (one-way ANOVA) using the GraphPad Prism 5 (GraphPad Software Inc., USA) with a probability level of $5 \%$.

Table 2. Chemical composition and carbohydrate fractions of the concentrates and experimental diets

\begin{tabular}{lccccccc}
\hline & \multicolumn{3}{c}{ Levels of citrus pulp (\%) } & \multicolumn{3}{c}{ Forage } \\
\hline \multicolumn{1}{c}{ Nutrients } & Control & $\mathbf{7}$ & $\mathbf{1 4}$ & $\mathbf{2 1}$ & $\mathbf{2 8}$ & Hay 1 & Hay 2 \\
\hline Dry matter & 89.24 & 90.01 & 90.68 & 90.41 & 90.83 & 86.56 & 86.52 \\
Organic matter & 84.91 & 85.63 & 85.91 & 85.26 & 85.3 & 79.24 & 78.83 \\
Calcium & 0.31 & 0.32 & 0.36 & 0.55 & 0.73 & & \\
Phosphorus & 0.32 & 0.34 & 0.31 & 0.28 & 0.25 & & \\
Mineral matter & 4.33 & 4.38 & 4.77 & 5.15 & 5.53 & 7.32 & 7.69 \\
Crude protein & 15.27 & 15.72 & 12.62 & 12.86 & 12.25 & 7.68 & 11.92 \\
Crude fiber & 5.02 & 5.78 & 5.80 & 6.05 & 6.97 & 32.5 & 34.32 \\
Ether extract & 3.76 & 3.89 & 3.50 & 2.92 & 2.78 & 1.03 & 0.87 \\
NFE & 70.96 & 70.23 & 73.31 & 73.02 & 72.47 & 48.25 & 45.2 \\
Natural detergent fiber & 15.92 & 15.86 & 15.62 & 15.47 & 16.44 & 79.8 & 78.23 \\
Acid detergent fiber & 12.43 & 12.89 & 12.87 & 12.55 & 12.7 & 41.79 & 54.5 \\
Non-fibrous carbohydrate & 60.72 & 60.15 & 63.49 & 63.60 & 63.00 & 4.00 & 1.29 \\
Soluble carbohydrate & 3.10 & 2.88 & 4.89 & 5.91 & 6.19 & 2.08 & 2.27 \\
Hemicellulose & 3.49 & 2.97 & 2.75 & 2.92 & 3.74 & 38.01 & 23.73 \\
Energy (Kcal/kg) & 3506.37 & 3511.88 & 3455.59 & 3397.21 & 3330.91 & 1923.83 & 1743.22 \\
\hline
\end{tabular}

Chemical composition and carbohydrate fractions of the experimental diets (forage: concentrate ratio $60: 40)$

\begin{tabular}{lccccc}
\hline Dry matter & 86.98 & 87.10 & 87.21 & 87.16 & 87.22 \\
Organic matter & 81.41 & 81.70 & 81.81 & 81.55 & 81.57 \\
Mineral matter & 6.21 & 6.23 & 6.39 & 6.54 & 6.69 \\
Crude protein & 11.73 & 11.91 & 10.67 & 10.77 & 10.53 \\
Ether extract & 2.08 & 2.14 & 1.98 & 1.75 & 1.69 \\
NFE & 56.60 & 56.31 & 57.54 & 57.43 & 57.21 \\
Natural detergent fiber & 53.87 & 53.85 & 53.75 & 53.69 & 54.08 \\
Acid detergent fiber & 33.10 & 33.28 & 33.27 & 33.14 & 33.20 \\
Non-fibrous carbohydrate & 26.04 & 25.81 & 27.15 & 27.19 & 26.95 \\
Soluble carbohydrate & 2.53 & 2.45 & 3.25 & 3.66 & 3.77 \\
Hemicellulose & 20.77 & 20.57 & 20.48 & 20.55 & 20.87 \\
Energy (Kcal/kg) & 2513.50 & 2515.70 & 2493.19 & 2469.84 & 2443.32 \\
\hline USA) with a probability level of $5 \%$ & & & & &
\end{tabular}

\section{Results and Discussion}

The increasing levels of citrus pulp on the diet had no effect $(P>0.05)$ on $\mathrm{pH}$ values and population 
counts of Lactabacillus spp and Streptococcus spp in feces of horses (Table 3).

The $\mathrm{pH}$ values observed in this study were similar to previous reports, ranging between 6.48 and 6.38 , affected by increasing levels of fructooligosaccharides (FOS) in diets for horses ${ }^{(2)}$, and approximate to those cited by Van Soest ${ }^{(13)}$, ranging from 6.4 to 6.7. Berg et al. ${ }^{(2)}$ observed a reduction in $\mathrm{pH}(P<0.05)$ as the FOS diet was included and attributed this result to increased production of SCFA. A similar situation was not observed in the present study. The $\mathrm{pH}$ stability of LAB and population examined in our laboratory could suggest that diets with increasing levels of citrus pulp do not allow the passage of the excess of easily fermentable carbohydrates into the large intestine and the quantity and quality of the hay provided together with the action of the citrus pulp kept the fermentation in the large intestine constant, which is useful to animal's health ${ }^{(13)}$.

Table 3. Average values of $\mathrm{pH}$ and count Lactabacillus spp and Streptococcus spp feces of horses fed with diets containig increasing levels of citrus pulp

\begin{tabular}{cccc}
\hline $\begin{array}{c}\text { Levels of citrus pulp } \\
\mathbf{( \% )}\end{array}$ & $\begin{array}{c}\text { Average pH } \\
\text { values }\end{array}$ & $\begin{array}{c}\text { Count of Lactobacillus } \\
\text { spp. (log ufc/g) }\end{array}$ & $\begin{array}{c}\text { Count of Streptococcus } \\
\text { spp. (log ufc/g) }\end{array}$ \\
\hline $\mathbf{0}$ & 6.50 & 7.27 & 7.27 \\
$\mathbf{7}$ & 6.35 & 6.98 & 7.84 \\
$\mathbf{1 4}$ & 6.47 & 7.05 & 7.21 \\
$\mathbf{2 1}$ & 6.53 & 7.03 & 7.28 \\
$\mathbf{2 8}$ & 6.67 & 7.02 & 7.76 \\
\hline
\end{tabular}

In the present study, no effect of the diets was observed $(P>0.05)$ on the population count of Lactobacillus spp and Streptococcus spp in horses feces. The optimum $\mathrm{pH}$ for activity of fiberfermenting bacteria is between 6.5 and 7.0, while bacteria that produces and uses lactate (Lactobacillus spp and Streptococcus spp) operates in lower $\mathrm{pH}^{(14)}$, which reinforces the results of the present study.

When horses were fed with diets containing $15 \mathrm{~g}$ probiotic (Saccharomyces cerevisiae), an increase $(P<0.05)$ in Lactobacillus and Streptococcus population was observed. The higher $\mathrm{pH}$ values occurred with the addition of probiotic, an increased utilization of lactate, and an elevation in ammonia nitrogen concentration.

The production of acidosis in the large intestine is linked to a greater production of SCFA and lactate, using FOS as the main substrate and soluble carbohydrates that escape the digestion in the small intestine $^{(14)}$. The use of diets containing higher intake of roughage help to maintain the $\mathrm{pH}$. This maintenance of $\mathrm{pH}$ can buffer the products of fermentation in the large intestine due to its rich dry matter content ${ }^{(15)}$.

This amount of roughage may also have affected the maintenance of the feces characteristics such as consistency and color. Feces consistency was classified as normal, indicating that there were no intraluminal changes, mainly in the tangent osmotic pressure. These results suggest that all of the acid generated by fermentation was properly buffered, and there was no influx of water into the large intestine to cause diarrhea ${ }^{(5)}$. The stool color (green) also reflected the typical coloration of coast-cross hay used in this study ${ }^{(10)}$.

There were differences $(\mathrm{p}<0.05)$ in feces consistency due to the diet, $98 \%$ were normal and firm, while only $2 \%$ of the horses had loose-type ruminant feces. Santos et al. ${ }^{(1)}$ observed, when working with an overload of starch, that feces became more fluid with the passage of time after eating. This effect on feces was attributed to the increased production of lactic acid in the large intestine that promotes increased intraluminal osmotic pressure, resulting in an osmotic influx of water into the intestinal lumen ${ }^{(1)}$. In the present study, it is possible that there was no overload of starch in the large intestine, as well as no change in lactic acid production, which could have been enhanced by maintaining the $\mathrm{pH}$ between treatments and maintaining populations of Lactobacillus spp and Streptococcus spp (Table 1). 
The color of feces showed no difference $(\mathrm{p}>0.05)$ between dietary treatments, and $100 \%$ had greenish coloration typical of the equine species. The typical green coloration is closely related to the type and quantity of forage offered to the animal. In the present study, $60 \%$ of dietary energy were offered coast-cross hay, which may have influenced the consistency and color of feces of horses ${ }^{(10,5)}$.

\section{Conclusions}

The inclusion of up to $28 \%$ citrus pulp in concentrate for horses did not promote change in physicochemical characteristics and does not interfere on the population of lactic acid-producing bacteria from feces.

\section{Acknowledgements}

The authors acknowledge the support of the Faculty of Animal Science and Food Engineering, University of São Paulo, and the financial support of the Coordination of Improvement of Higher Education Personnel (CAPES).

\section{Informative Notes}

The research project titled "Physicochemical and microbiological feces of horses fed with diets containing citrus pulp" (Protocol: 06/2012), developing in the period July-December 2012, was approved "by referendum" by the Management Council Pirassununga Campus Faculty of Animal Science and Food Engineering - FZEA.

\section{References}

1. Santos TM, Almeida FQ, Godoi FN, Silva VP, França AB, Santiago JM, Santos CS. Capacidade tamponante, $\mathrm{pH}$ e consistência das fezes em equinos submetidos à sobrecarga dietética com amido. Ciência Rural [Internet], 2009; 39:1782-1788. Available from: http://dx.doi.org/10.1590/S0103-84782009005000123

2. Berg EL, Fu CJ, Porter JH, Kerley MS. Fructooligosaccharide supplementation in the yearling horse: effects on fecal $\mathrm{pH}$, microbial content, and volatile fatty acid concentrations. Journal of Animal Science [Internet], 2005; 83:1549-1553. Available from: http://www.journalofanimalscience.org/content/83/7/1549.full.pdf + html

3. Jouany JP, Gobert, J, Medina, B., Bertin, G, Julliand, V. Effect of live yeast culture supplementation on apparent digestibility and rate of passage in horses fed a high - fiber or high-starch. Journal of Animal Science, 86:339-347, 2008.

4. Williamson A, Rogers CW, Firth EC. A survey of feeding, management and faecal $\mathrm{pH}$ of Thoroughbred racehorses in the North Island of New Zealand. New Zealand Veterinary Journal [Internet], 2007; 55(6):337341. Available from: http://dx.doi.org/10.1080/00480169.2007.36790

5. NRC. National Research Council of the National Academies. Nutrient Requirements of Horses. 6th ed. Washington:National Academy Press; 2007.

6. Vervuet, I, Voigt, K., Hollands, T., Cudderford, D., Coenen, M. Effect of feeding increasing quantities of starch on glycaemic and insuminaemic responses in healthy horses. The Veterinary Journal. v.182, p.67-72, 2009.

7. Furtado CE, Brandi RA, Ribeiro LB. Utilização de coprodutos e demais alimentos alternativos para dietas de 
equinos no Brasil. Revista Brasileira de Zootecnia [Internet], 2011; 40:214-223. Available from: http://www. sbz.org.br/revista/artigos/66278.pdf

8. Moreira, C. G., Brandi, R. A. ; Bueno, I. C. S., Menezes, M. L., Mota, T. P., Souza, A. D., Tavares, A. F., Augusto, L. S. Palatability and digestibility of horse diets containing increasing levels of citrus pulp. MVZ Cordoba, v. 20, p. 4546-4557, 2015.

9. Al Jassim RA, Scott PT, Trebbin AL, Trott D, Pollitt CC. The genetic diversity of lactic acid producing bacteria in the equine gastrointestinal tract. FEMS Microbiology Letters [Internet], 2005; 248:75-81. Available from: http://onlinelibrary.wiley.com/doi/10.1016/j.femsle.2005.05.023/pdf

10. Godoi FN, Almeida FQ, Guarienti GA, Santiago JM, Guedes Júnior D, Nogueira YC, Brasileiro LS. Perfil hematólogico e características das fezes de equinos consumindo dietas hiperlipidêmicas. Ciência Rural [Internet], 2009; 39 (9):2571-2577. Available from: http://dx.doi.org/10.1590/S0103-84782009000900029

11. Hartemink R, Domenech VR, Rombouts FM. LAMVAB - a new selective medium for the isolation of lactobacilli from faeces. Journal Microbiological Methods 1997; 29(2):77-84. Available from: http://ac.elscdn.com/S0167701297000250/1-s2.0-S0167701297000250-main.pdf

12. SAS INSTITUTE. The SAS system for windows. Release 8.01. Cary, 2000.

13. Van Soest P.j., Robertson, J.B., Lewis, B.A. Methods for Dietary Fiber, Neutral Detergent Fiber, and Nonstarch Polysaccharides in Relation to Animal Nutrition. Journal of Dairy Science, Vol. 74, nº 10, 1991.

14. Santos, T.M., Almeida, F.Q., Godoi, F.N., Silva, V.P., França, A.B., Santiago, J.M., Santos, C.S. Capacidade Tamponante $\mathrm{pH}$ e consistência das fezes em equinos submetidos à sobrecarga dietética com amido. Ciência Rural, v.39, n.6, set, 2009.

15. Furtado C.E, Barbosa ED, Brandi RA, Ribeiro LB, Oliveira AAMA. Uso de levedura em equinos alimentados com dietas compostas de fenos de diferentes qualidades nutricionais. Revista Brasileira de Zootecnia [Internet], 2010; 39:2194-2199. Available from: http://www.scielo.br/pdf/rbz/v39n10/14.pdf 